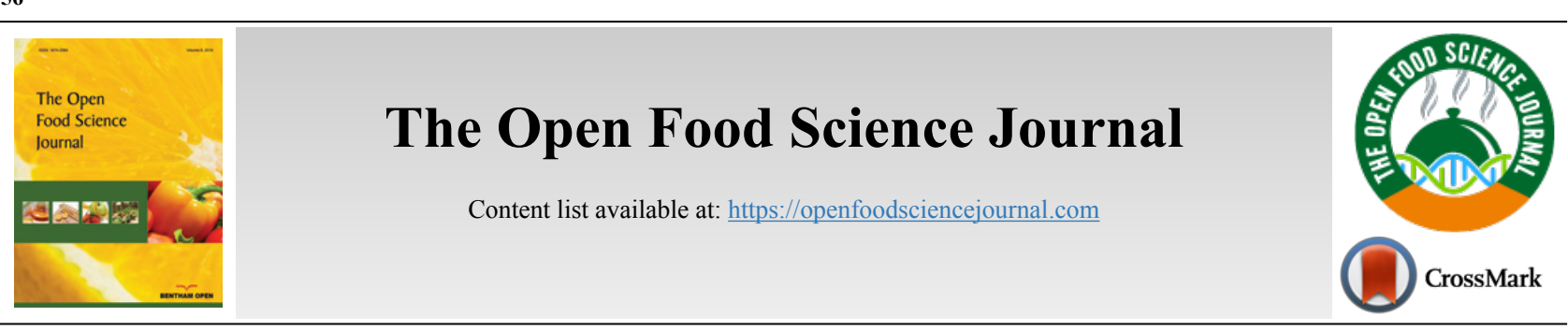

RESEARCH ARTICLE

\title{
Antioxidant Activity and Phenolic Content of Campomanesia Phaea Extracts Obtained by Pressurized Liquid Extraction
}

\author{
Daniele Martins Firmiano, Gabriela Marques Bittencourt and Alessandra Lopes de Oliveira* \\ Departamento de Engenharia de Alimentos da, Faculdade de Zootecnia e Engenharia de Alimentos da, Universidade de São Paulo (USP/FZEA), \\ Brazil
}

\begin{abstract}
:
Objective:

This research used the Pressurized Liquid Extraction process (PLE) to obtain cambuci extracts rich in phenolic compounds and, consequently, with high antioxidant activity.

Methods:

We determined the centesimal composition and the mean particle size of the dried and crushed sample for characterization of the fixed bed extractor. Extractions with pressurized ethanol were performed following a Central Composite Design (CCD) with temperature $\left(60{ }^{\circ} \mathrm{C}\right.$ at the center point with $\pm 10{ }^{\circ} \mathrm{C}$ amplitude) and the contact time between the solvent and the matrix ( 6 min at the center point with \pm 2 min amplitude) as independent variables in the process. The Total Phenolic Content (TPC) of compounds and antioxidant activity were determined.

Results:

The mean particle size of the cambuci in the PLE was $263.4 \mu \mathrm{m}$ with apparent and real densities of $32.42 \mathrm{~g} / \mathrm{cm}^{3}$ and $1.62 \mathrm{~g} / \mathrm{cm}^{3}$, respectively, resulting in a fixed bed porosity of 0.43 . The centesimal composition of the comminuted and dried sample was $12.5 \pm 0.1 \%$ moisture, $3.2 \pm 0.2 \%$ ash, $3.35 \pm 0.07 \%$ crude protein, $10.32 \pm 0.08 \%$ crude fiber and $0.35 \pm 0.04 \%$ ethereal extract. The highest extraction yield $(41.7 \%)$ was obtained by using the binomial $70^{\circ} \mathrm{C}$ with 8 min of solvent contact in three batches. Extracts with the highest TPC (6501.10 mg AGE/100 g sample) were obtained by the binomial $74{ }^{\circ} \mathrm{C}$ with $6 \mathrm{~min}$ of contact; the binomial $50{ }^{\circ} \mathrm{C}$ with $4 \mathrm{~min}$ of contact gave rise to the extract with the highest antioxidant activity. The CCD showed high yield extracts with high antioxidant activity and a high total phenolic compound content.

Conclusion:

With the use of the proposed experimental design, it was possible to optimize the extraction of total phenolic compounds from the sample.
\end{abstract}

Keywords: Cambuci, Antioxidant activity, Pressurized liquid extraction, Total phenolic content, Brazilian forest, Essential oil.

\begin{tabular}{|l|l|l|r|}
\hline Article History & Received: October 19, 2018 & Revised: February 07, 2019 & Accepted: February 18,2019 \\
\hline
\end{tabular}

\section{INTRODUCTION}

There is great interest in the search for industrial applications and the sustainable economic use of the natural resources of Brazilian biomes, especially the Atlantic Forest, as a means of avoiding extinction and maintaining legal reserves. A legal reserve is a mechanism for the protection of native vegetation cover within private rural property and is provided for in Law No. 12,651 of the Brazilian Forest Code of 25 May 2012 [1]. The study of the collection and composition of extracts using innovative technology to obtain active

* Address correspondence to this author at the Avenida Duque de Caxias Norte, 225, Caixa Postal 23, Pirassununga, SP,Brazil, CEP: 13635-900;

Tel: (+5519)35654268; Fax: (+5519)35654284; E-mail: alelopes@usp.br. compounds free from organic solvents contributes to the development of new products derived from this biome and, consequently, encourages their preservation.

Brazil has vast flora diversity due to its climate, soil and territorial extent, in which little known species are found, such as cambuci (Campomanesia phaea). The chemical composition of cambuci fruits is like that of other Myrtaceae species, such as pitanga [2]. Cambuci currently occurs in the states of São Paulo and Minas Gerais, in the Serra do Mar slope that extends to the plateau of São Paulo, and at the beginning of the plateau towards the interior, in an area called the Coastal Atlantic Forest. It is one of the types of vegetation that is at risk of extinction. The height of its trunk varies from 3 to $5 \mathrm{~m}$, and its 
diameter ranges from 20 to $30 \mathrm{~cm}$. The leaves of this species have a high essential oil content and are rich in linalool $(11.1 \%)$, caryophyllene oxide $(11.8 \%)$, beta caryophyllene (6.3\%), betasselinene $(6.3 \%)$ and alphacadinol $(9 \%)$, which are constituents with a high commercial value for the pharmaceutical and cosmetics industries [2].

The characteristics of the fruit include a fine peel and a green color. In this way, the fruit ripens when it becomes softer and falls off the branches. Although it is rich in nutritional value, fruit consumption in natura is limited due to its strong acidity, even with its strong sweet scent. As its taste and aroma qualities are not lost through processing, cambuci is widely used as a flavoring agent and in the preparation of juices, jellies and jams, as a syrup [3]. The fruits, in general, have a rhomboid shape and are quite aromatic. However, there is great variation in their dimensions due to its occurrence extending from mountainous regions to areas near sea level, which can cause not only a morphological variation but also a variation in the chemical composition of these fruits [4].

Many studies have shown that free radicals are the main cause of various degenerative diseases, such as cardiovascular, neurological and some forms of cancer. The antioxidants present in plants can act as reducing agents for free radicals, enzyme inhibitors and as metal chelators; most of their biologically active effects are derived from antioxidant functions. Natural antioxidants can improve food quality and stability, act as nutraceuticals and provide additional health benefits to consumers [5]. Natural antioxidants, present in the diet, increase resistance to damage caused by oxidation, so they are important for maintaining human health. Antioxidant activity refers to compounds that can inhibit or assert the oxidation of molecules. Most antioxidant compounds cannot be synthesized by the human body and need to be introduced through a diet rich in fruits and vegetables [6]. Active compounds commonly found in fruits and vegetables, which are phenolic substances, are known as potent antioxidants and are natural antagonists of pathogens. These substances are found in plants in a free form or linked to sugars and proteins. As natural antioxidants, in addition to being alternative compounds that avoid the oxidative deterioration of foods, they can also exert an important physiological role, minimizing oxidative damage in animal organisms [5]. Food industries use antioxidants to prevent product deterioration and maintain nutritional value, whereas biochemists and health care professionals use antioxidants to help protect the body against the damage caused by reactive oxygen species. Natural antioxidants include tocopherols, vitamin $\mathrm{C}$, carotenoids and phenolic compounds [7].

Several researchers have been studying the separation, identification, quantification and application of phenolic compounds in foods, but they have faced many methodological problems; besides, containing a huge quantity of substances, phenolic compounds are, in most cases, very polar, very reactive and susceptible to the action of enzymes. Therefore, the analysis of phenolic compounds is influenced by the nature of the compound, the extraction method employed, the sample size, the time and storage conditions, the standard used and the presence of interferers, such as waxes, fats, terpenes and chlorophylls [8]. Pressurized Liquid Extraction (PLE) is based on the use of organic solvents subjected to an elevated temperature and pressure in order to extract certain solid or semi-solid matrix compounds in a short time, with the use of a small amount of solvent. Elevated temperature values increase solubility, diffusion rate and mass transfer, while the viscosity and surface tension values of the solvent are lower than those at room temperature. The solvents commonly used in PLE processes are methanol, ethanol, isopropanol, acetone, hexane, diethyl ether and water, which have been increasingly used in the extraction of phenolic compounds such as phenolic acids and flavonoids due to their high polarity, dielectric constant and numbing ability [9]. Some of these solvents, like isopropanol, ethanol and water, are GRAS (Generally Recognized as Safe) and, because it is safe for health, it can be used for food or drug processing. The other solvent is not GRAS and is generally used only for analytical purposes.

The objective of this research was to optimize the extraction process with pressurized liquid (PLE) to obtain cambuci extracts rich in phenolic compounds and, consequently, with high antioxidant activity.

\section{MATERIALS AND METHODS}

\subsection{Raw Material}

The raw material used in this research was cambuci of the species Campomanesia phaea, cultivated in Pirassununga, located in the centre-east region of the state of São Paulo, at latitude $21^{\circ} 59^{\prime} 46^{\prime \prime}$ South and longitude 47 $25^{\prime} 36^{\prime \prime}$ West, and at an altitude of 625 metres [10]. This material was generously donated by Prof. Dr. Rogério Lacaz Ruiz.

The fruits were dried in an oven with forced air circulation at $45^{\circ} \mathrm{C}$ until they reached a constant weight (approximately 72 h). They were subsequently crushed (Marconi, MA 340, Pira cicaba, Brazil), packed in plastic containers and stored at $-22^{\circ} \mathrm{C}$.

\subsection{Sample Characterization}

The centesimal composition of the sample was calculated by a determination of the dry matter, crude protein, crude fiber, mineral matter and ethereal extract, following the methodologies described by AOAC [11]. Granulometry was determined using a set of six sieves of the standard Tyler series. Apparent density ( $\rho a)$ was determined by the ratio between the mass of the crushed sample conditioned in the packing of the fixed bed of the extractor at $32.42 \mathrm{~cm}^{3}$. Real density ( $\rho r)$ was determined by helium gas pycnometry. The porosity of the bed $(\varepsilon)$ was calculated by the relation between apparent density and actual density.

\subsection{Pressurised Liquid Extraction of Cambuci}

Cambuci extraction used ethanol (AppliChem, Darmstadt, DE) as a solvent and was performed using ASE ${ }^{2} 150$ equipment, Dionex (Thermo Fisher Scientific Inc., Waltham, Massachusetts, USA), which accelerates the traditional extraction process by using a low volume of solvent at a controlled pressure and temperature in order to maintain the solvent in the liquid state throughout the extraction; after the 
stipulated contact time, the extract is withdrawn from contact with the sample and directed to a collection vessel and is, thus, ready to be analysed. Ethanol was chosen as a solvent for being GRAS and for being polar, therefore having an affinity with the compounds of interest of this work and the possibility of being employed in future processing of this plant matrix.

The $10 \mathrm{~g}$ samples were conditioned in a $34 \mathrm{~mL}$ extraction cell. The experiment followed the experimental Central Composite Design (CCD) presented in Table 1, with temperature and contact time between the solvent and the plant matrix in each cycle as independent fixed constant variables. The number of cycles corresponds to the number of times the solvent meets the sample in the extractor; in these experiments, the total volume was divided into four cycles and $120 \%$ of the cell volume, so, in each cycle, $10.2 \mathrm{~mL}$ of solvent was circulated.

\subsection{Total Phenolic Content}

The Total Phenolic Content (TPC) was determined following the methodology described by Singleton and Rossi [12], in which $1 \mathrm{~mL}$ of diluted extract in chromatographic grade methanol (AppliChem, Darmstadt, DE) at $1 \mathrm{mg} / \mathrm{mL}$ is added to $5 \mathrm{~mL}$ of Folin-Ciocalteu reagent solution (Scientific
Exodus, Hortolândia, BR) diluted in demineralized water. After $10 \mathrm{~min}$ of contact, $4 \mathrm{~mL}$ of aqueous solution with $7.5 \%$ analytical standard anhydrous sodium carbonate (Synth, Diadema, BR) is added. Absorbance measurements were performed using a spectrophotometer (Genesys 10s UV-Vis, Thermo Scientific, Massachusetts, USA) at $760 \mathrm{~nm}$ after 2 hours.

\subsection{Antioxidant Activity}

In the study of the optimization of processes to obtain extracts rich in active compounds, different methods for the analysis of the antioxidant activity can be used, nonetheless, in this research, there was no intention to compare methods of analysis, but to evaluate this property in the extracts. For the analysis of the antioxidant activity of the extracts, the method described by Brand-Willams, Cuvelier and Berset [13] was used, which is based on the capture of the organic radical DPPH. The extracted samples were diluted in methanol (AppliChem, Darmstadt, DE) at concentrations of 0.05 to 500 $\mathrm{mg} / \mathrm{mL}$. After this, $1950 \mu \mathrm{L}$ of DPPH solution in methanol and $50 \mu \mathrm{L}$ solution-containing a sample was added to perform a $515 \mathrm{~nm}$ absorbance reading using a spectrophotometer (Genesys 10s UV-Vis, Thermo Scientific, Massachusetts, USA),

Table 1. Overall yield, phenolic compounds content and antioxidant activity of Cambuci ethanolic extracts obtained in the essay performed according to the proposed DCCR.

\begin{tabular}{|c|c|c|c|c|c|c|c|}
\hline \multirow{3}{*}{ Assay } & \multicolumn{2}{|c|}{ Real Variables } & \multicolumn{2}{|c|}{ Codified Variables } & \multirow{3}{*}{ Yield (\%) } & \multirow{3}{*}{$\begin{array}{c}\text { TPC } \\
\text { (mg GAE/100g sample) }\end{array}$} & \multirow{3}{*}{$\operatorname{EC50}(\mathrm{mg} / \mathrm{mL})$} \\
\hline & $T$ & St & $T$ & St & & & \\
\hline & $\left({ }^{\circ} \mathrm{C}\right)$ & (min) & $\left({ }^{\circ} \mathrm{C}\right)$ & $(\min )$ & & & \\
\hline 1 & 50 & 4 & -1 & -1 & 23.96 & 4015.57 & 3.44 \\
\hline 2 & 70 & 4 & +1 & -1 & 30.81 & 5514.60 & 8.57 \\
\hline 3 & 50 & 8 & -1 & +1 & 28.65 & 3967.48 & 8.78 \\
\hline 4 & 70 & 8 & +1 & +1 & 41.72 & 6305.53 & 10.42 \\
\hline 5 & 46 & 6 & -1.41 & 0 & 28.44 & 3974.40 & 11.25 \\
\hline 6 & 74 & 6 & +1.41 & 0 & 32.22 & 6501.10 & 8.00 \\
\hline 7 & 60 & 3 & 0 & -1.41 & 25.48 & 4173.56 & 8.81 \\
\hline 8 & 60 & 9 & 0 & +1.41 & 33.21 & 3842.27 & 10.09 \\
\hline $9 *$ & 60 & 6 & 0 & 0 & 29.07 & 6159.90 & 6.58 \\
\hline $10^{*}$ & 60 & 6 & 0 & 0 & 30.00 & 6470.89 & 6.32 \\
\hline $11^{*}$ & 60 & 6 & 0 & 0 & 30.04 & 6517.54 & 7.60 \\
\hline
\end{tabular}

Table 2. Analysis of variance (ANOVA) for yield in the experimental design (residual error).

\begin{tabular}{|c|c|c|c|c|c|}
\hline $\begin{array}{l}\text { Source of } \\
\text { Variation }\end{array}$ & $\begin{array}{c}\text { Sum of } \\
\text { Squares }\end{array}$ & $\begin{array}{l}\text { Degrees of } \\
\text { Freedom }\end{array}$ & $\begin{array}{c}\text { Medium } \\
\text { Square }\end{array}$ & Fealc & Ftable \\
\hline \multicolumn{6}{|c|}{ First order model } \\
\hline Regression & 169.71 & 3 & 56.57 & \multirow{3}{*}{34.70} & \multirow{3}{*}{9.28} \\
\hline Residue & 4.89 & 3 & 1.63 & & \\
\hline Total & 174.60 & 6 & - & & \\
\hline \multicolumn{6}{|c|}{ Second order model } \\
\hline Regression & 180.25 & 5 & 36.05 & \multirow{3}{*}{5.32} & \multirow{3}{*}{5.05} \\
\hline Residue & 33.85 & 5 & 6.77 & & \\
\hline Total & 214.10 & 10 & - & & \\
\hline
\end{tabular}


with one reading per minute, until the reading stabilized. In this method, the extract reacts with DPPH radical solution in methanol, causing a reduction of the DPPH radical and observing its variation in a characteristic wavelength. In its free radical form, DPPH absorbs at $515 \mathrm{~nm}$, but after reduction, this absorption disappears [13]. This reduction of the radical can also be clearly noticed by the alteration of the violet color of the solution, which undergoes discoloration when it encounters antioxidant molecules, becoming yellowish.

Antioxidants are substances that retard the oxidation rate, through one or more mechanisms, such as the inhibition of free radicals. These antioxidants may be synthetic or natural and, for use in food, should be safe for health. The free radical method is based on the bleaching of a solution composed of stable violet DPPH radicals, in which the addition of substances can yield a hydrogen atom and turn yellow. This method is based on the transfer of electrons from an antioxidant compound to an oxidant. In this way, it only evaluates the reducing power of the antioxidant, which, when donating an electron, oxidizes [14].

\subsection{Statistical Analysis}

Statistical analyses were performed using PROTIMIZA Experimental Design software, Campinas - SP. To verify if the process variables, Temperature $(\mathrm{T})$, Static time (St), influenced the TPC, the main effects were evaluated through an analysis of variance (ANOVA) considering a significance level of $95 \%$ for all analyses.

\section{RESULTS AND DISCUSSION}

\subsection{Sample Characterization}

Fig. (1) shows cambuci in natura (A) and in the form used in the extractions [dry (B) and crushed (C)]. After being dried and crushed, this fruit had $12.5 \pm 0.1 \%$ moisture, $3.2 \pm 0.2 \%$ mineral matter, $3.35 \pm 0.07 \%$ crude protein, $10.32 \pm 0.08 \%$ crude fiber and $0.35 \pm 0.04 \%$ ethereal extract. Centesimal composition analyses are important for delineating the extraction processes.

It is also necessary to identify the particle size of the sample and the fixed bed porosity because these factors influence the extract yield; the humidity and the reduction of particles interfere in the area of contact of the solvent and, consequently, in the mass transfer. The size profiles of the sample were $0.55 \mathrm{~g}$ with a diameter $(\mathrm{d}) \geq 1700 \mu \mathrm{m}, 0.86 \mathrm{~g}$ with a diameter, $1700 \mu \mathrm{m}>\mathrm{d} \geq 1180 \mu \mathrm{m}, 17.09 \mathrm{~g}$ with a diameter $1180 \mu \mathrm{m}>\mathrm{d} \geq 850 \mu \mathrm{m}, 43.995 \mathrm{~g}$ with a diameter $850 \mu \mathrm{m}>\mathrm{d} \geq$ $600 \mu \mathrm{m}, 26.685 \mathrm{~g}$ with a diameter $600 \mu \mathrm{m}>\mathrm{d} \geq 425 \mu \mathrm{m}, 17.06$ g with diameter a $425 \mu \mathrm{m}>\mathrm{d} \geq 300 \mu \mathrm{m}$ and $43.215 \mathrm{~g}$ with a diameter $<300 \mu \mathrm{m}$.

The sample mass found at the bottom of the sieve, corresponding to the particle diameter smaller than $300 \mu \mathrm{m}$, corresponded to $28.41 \%$ of the total mass used (149.45 g) and can not be disregarded, therefore, the mean diameter of these particles was measured using laser diffraction; an average value of $0.017 \mathrm{~mm}$ in diameter was observed. The mean particle size in the cambuci sample, considering both measuring techniques, was $263.4 \mu \mathrm{m}$.

The apparent density of the sample was $0.70 \mathrm{~g} / \mathrm{cm}^{3}$. The real density of the dried and grounded cambuci sample, determined by helium gas pycnometry, was $1.62 \mathrm{~g} / \mathrm{cm}^{3}$. The bed porosity was calculated by the ratio of apparent density to actual density, and a value of 0.43 was obtained.

\subsection{Extraction Yield}

Table 1 shows the cambuci extraction yields, obtained with pressurized ethanol, for the 11 assays; these were calculated by the ratio between the solvent-free extract mass at the end of the extraction and the mass of the sample packed in the fixed bed extractor. The assay that presented the highest yield during the extraction process was assay 4 , whose temperature was $70^{\circ} \mathrm{C}$ and static time was 8 minutes. The lowest yield was from assay 1 , with a temperature of $50^{\circ} \mathrm{C}$ and a static time of 4 minutes. The Pareto diagram shows that both Temperature (T) and Static time (St) significantly influenced the extraction yield at the $95 \%$ level of significance and that the effect of the interaction between the variables $(\mathrm{T} \times \mathrm{St})$ had no significant influence Fig. (2). In the analysis of variance of the first and second order models, which can predict the influence of the PLE process variables (Table 2), we verified that at least one of the studied variables had a significant effect on the analyzed parameter, with a $95 \%$ confidence level, because the calculated
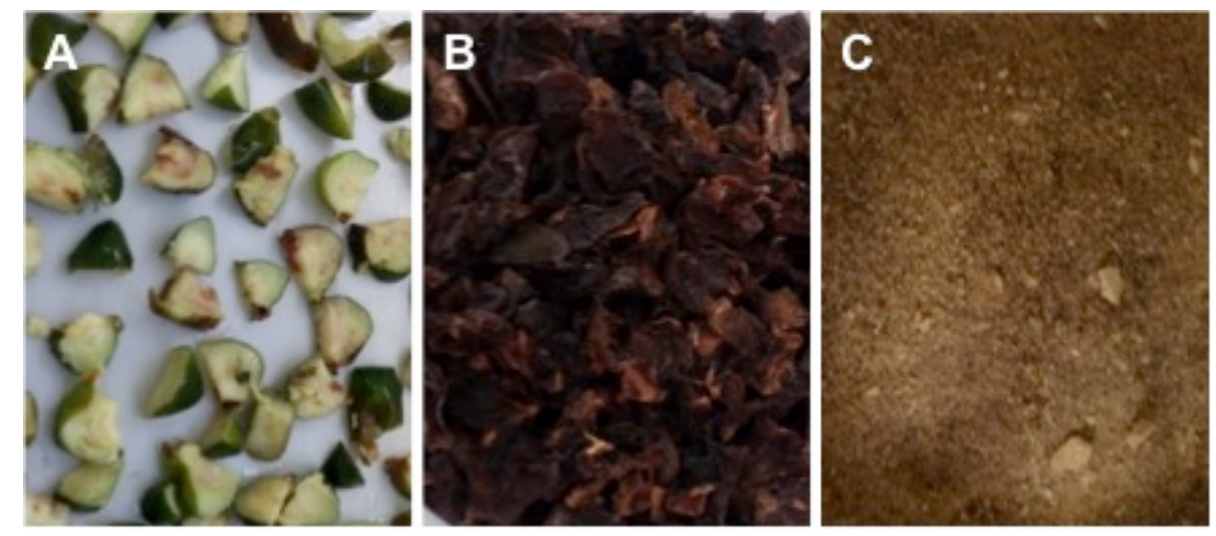

Fig. (1). (a) Cambuci fruit in natura, (b) dry (c) e crushed. 

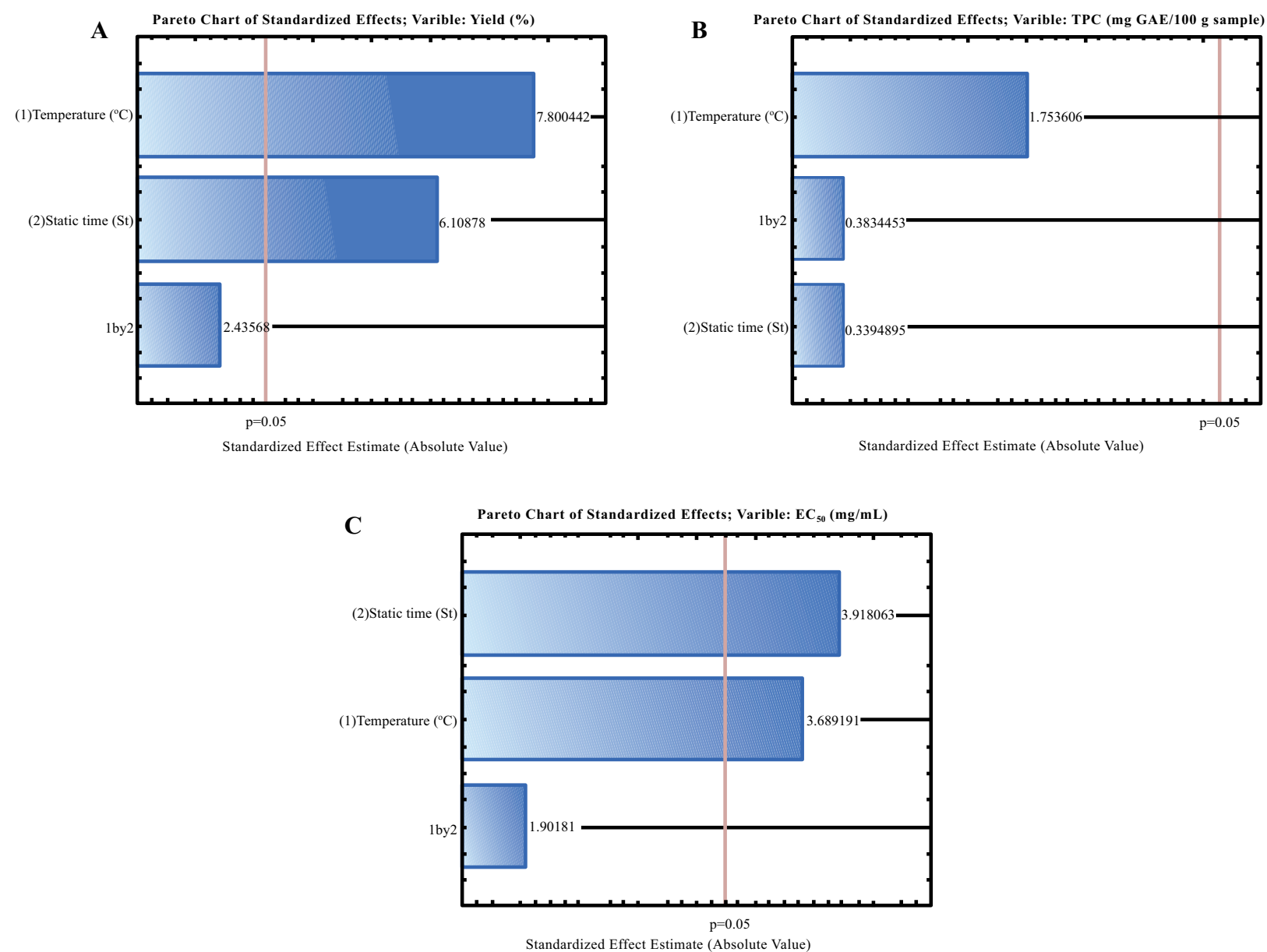

Fig. (2). Pareto diagrams of the studied independent variables effects on the dependent variables A) extraction yield, B) TPC e C) antioxidant activity.

$\mathrm{F}$ test $\left(\mathrm{F}_{\text {calc }}, 34.70\right.$ for first order model and 5.32 for second order model) was larger than the tabulated $\mathrm{F}\left(\mathrm{F}_{\text {table }}, 9.28\right.$ for first order model and 5.05 for second order model) for both models. The first order mathematical model (Eq. 1) presented a regression coefficient of 0.97 and the second-order mathematical model (Eq. 2) presented a regression coefficient of 0.84 . In the models, significant terms are marked with an asterisk $(*)$.

$$
\begin{aligned}
Y & =30.61 *+9.96 T^{*}+7.80 S t^{*}+T \times S t \\
Y & =29.69 *+6.33 T^{*}+1.36 T 2+6.64 S t^{*} 0.37 S t 2+ \\
& +3.11 T \times S t
\end{aligned}
$$

The yields of cambuci extracts ranged from $23.96 \%$ to $41.72 \%$, and higher values were obtained for high $\mathrm{T}$ and $\mathrm{St}$ values, thus, the variables positively influenced the extraction. In the response surface generated by the second-order model Fig. (3), it is possible to observe this behavior.

In the study of extraction process involving pressurized ethanol to obtain active compounds of Brazilian plants, conducted by our research group [15 - 17] this process has shown that the influence of these variables is always positive, regardless of the raw material studied. It is noteworthy that varying these conditions while maintaining the fixed ethanol volume implies a solvent economy.

\subsection{Total Phenolic Content}

In the study of the extract process, in addition to the yield of the extracts, one must determine the concentration of compounds that may attribute activity to these extracts. To identify the total phenolic content, a standard curve was used, obtained from different concentrations of gallic acid diluted in methanol. The linear adjustment of the points related to the different concentrations of gallic acid to the absorbance of these solutions generated Eq.(3), with a regression coefficient of 0.997 .

$$
G A E=0.0079 a b c+0.0026
$$

where $a b s$ is the absorbance measured with a spectrophotometer.

The Total Phenolic Content (TPC) of the extracts was obtained by correlating the absorbance of the solution (after the oxide reduction reaction) at the $760 \mathrm{~nm}$ wavelength, for each cambuci ethanolic extract obtained in each DCCR assay, with Eq. (3); values are presented in Table 1. 

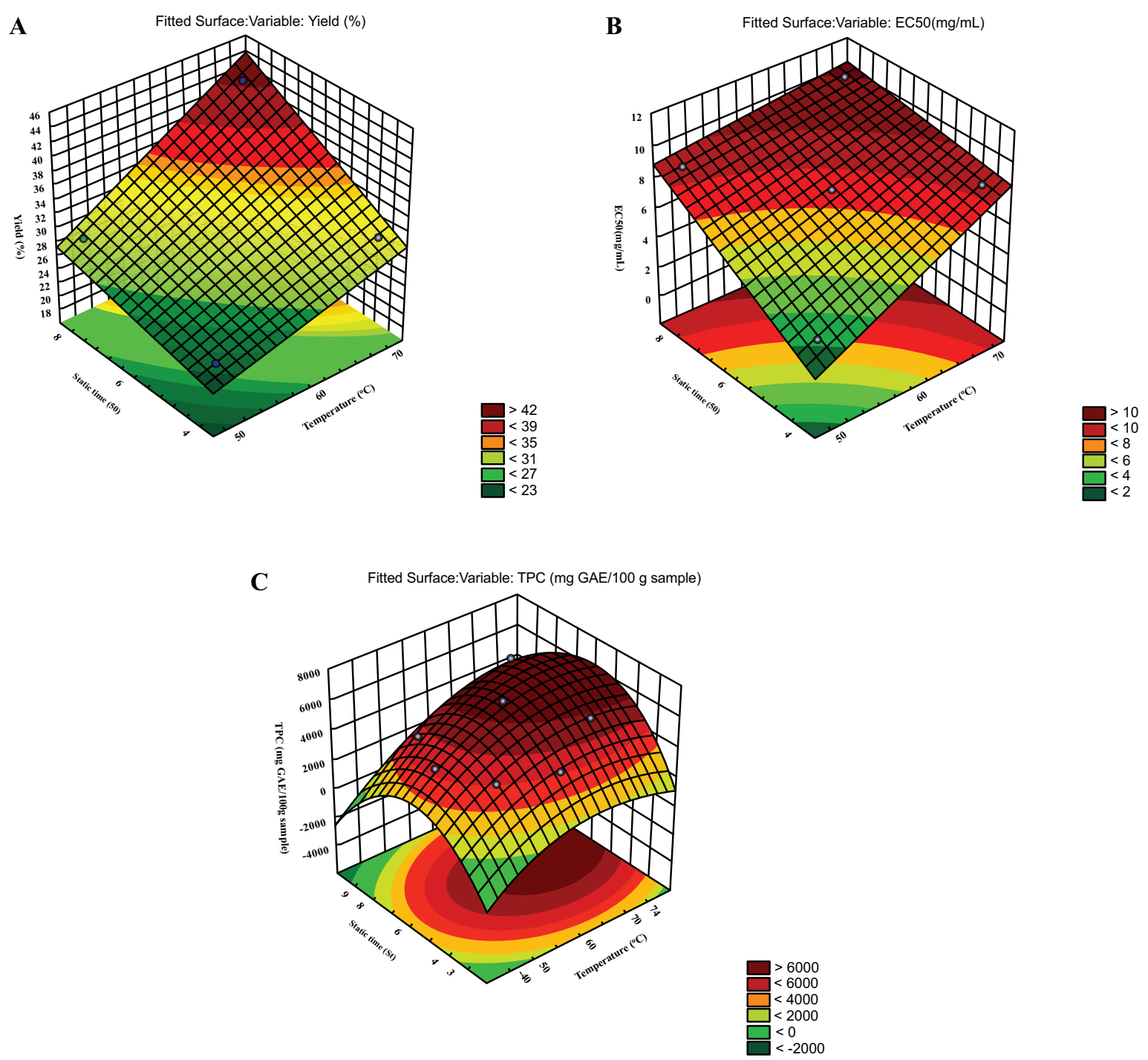

Fig. (3). Response surfaces generated A) by the first order model that describes the effects of the independent variables on the extraction yield, B) by the second order model that describes the effects of the independent variables on TPC and C) by the first order model that describes the effects of independent variables on antioxidant activity.

TPC of ethanolic extracts ranged from 3842.27 to 6517.54 mg GAE $/ 100 \mathrm{~g}$ sample. The central point assay, using an intermediate temperature $\left(60^{\circ} \mathrm{C}\right)$ and static time $(6 \mathrm{~min})$ had the highest content of reagent compounds with Folin-Ciocalteu. The lowest concentration of these compounds was found in the extract obtained by assay 8 in the DCCR $\left(60^{\circ} \mathrm{C}\right.$ for 9 min of static time in each cycle), probably due to the high static time employed, which may have destroyed the thermosensitive compounds of interest.

As the largest and smallest TPC was found in the extracts obtained by tests that used the same extraction temperature, varying only the static time, it can be observed that the independent variable static time is inversely related to the TPC of the cambuci ethanolic extracts.

Despite what can be observed in the analysis of the values presented in Table 1, the Pareto diagram Fig. (2), indicates that none of the independent variables, nor the interaction between them, significantly influenced the phenolic compound content.

The ANOVA for the first models Table 3 showed that, for the first order model, no variable had a significant effect on the $\mathrm{TPC}$ at the $95 \%$ significance level, since there was no effect of these variables, as demonstrated by the Pareto diagram Fig. (2). However, for the second order model, at least one of the variables had a significant effect on the TPC since $F_{\text {calc }}>F_{\text {table, }}$, $28.52>5.05$. However, the coefficient of determination of this model $\left(R^{2}\right)$ was 0.97 . The influence of temperature $(T)$, static time $(\mathrm{St})$ and the interaction between these independent variables $(\mathrm{T} \times \mathrm{St})$ on the TPC can also be observed through the analysis response surface (RSA), It was possible to obtain an optimal region generated by the second-order model Fig. (2). It can be inferred that there is an optimized region, indicating that higher TPC from the cambuci extracts are obtained when the temperature is between $65^{\circ} \mathrm{C}$ and $70^{\circ} \mathrm{C}$ and intermediate contact time in each cycle is about $6 \mathrm{~min}$. 
Table 3. Analysis of variance (ANOVA) for TPC in the Cambuci extracts from the experimental design (residual error).

\begin{tabular}{|c|c|c|c|c|c|}
\hline $\begin{array}{l}\text { Source of } \\
\text { Variation } \\
\end{array}$ & $\begin{array}{c}\text { Sum of } \\
\text { Squares } \\
\end{array}$ & $\begin{array}{c}\text { Degrees of } \\
\text { Freedom } \\
\end{array}$ & $\begin{array}{c}\text { Medium } \\
\text { Square }\end{array}$ & Fcalc & Ftable \\
\hline \multicolumn{6}{|c|}{ Second order model } \\
\hline Regression & 3994737 & 3 & 1331579 & \multirow{3}{*}{1.11} & \multirow{3}{*}{9.28} \\
\hline Residue & 3590865 & 3 & 1196955 & & \\
\hline Total & 7585602 & 6 & - & & \\
\hline \multicolumn{6}{|c|}{ Second order model } \\
\hline Regression & 14107567 & 5 & 2821513 & \multirow{3}{*}{28.52} & \multirow{3}{*}{5.05} \\
\hline Residue & 494669 & 5 & 98934 & & \\
\hline Total & 14602236 & 10 & - & & \\
\hline
\end{tabular}

\subsection{Antioxidant Activity}

In addition to a study of composition, the search for extract activity is also done through the study of process optimization. The kinetic behavior of the DPPH radical reaction with some extracts, in concentrations ranging from $500 \mathrm{mg} / \mathrm{mL}$ to 0.05 $\mathrm{mg} / \mathrm{mL}$, is presented in Fig. (4). This kinetic behavior shows the consumption of the DPPH radical as a function of time in minutes, indicating the time the extract takes to decrease the concentration of its antioxidant agents. Natural extracts that have a high rate of antioxidant activity can be used in foods to increase their shelf life by avoiding the oxidation of their constituents. As seen in the examples in Fig. (4), the samples showed rapid kinetics, practically reaching the maximum consumption of DPPH within the first few minutes.

The determination of the efficient concentration $\left(\mathrm{EC}_{50}\right)$, or the sample concentration that causes $50 \%$ inhibition of the initial concentration of DPPH, was obtained by linear regression of the plotted plot points. The results of this analysis are presented in Table 1 and ranged from 3.44 to $11.25 \mathrm{mg} / \mathrm{mL}$. An extract that presents high potential in sequestering free radicals has a low $\mathrm{EC}_{50}$ value. Thus, a small amount of extract can decrease the initial concentration of the DPPH radical by $50 \%$, that is, to inhibit the radical oxidation by $50 \%$; the lower this concentration, the better the antioxidant compound. An extract that has a high potential in sequestering free radicals has a low $\mathrm{EC}_{50}$ value [18]. The extract that presented the lowest $\mathrm{EC}_{50}$ was that obtained from assay 1 (Table 1), in which a lower temperature and a shorter contact time between the solvent and the matrix were used. Comparing the results of the antioxidant activity of cambuci that presents an $\mathrm{EC}_{50}$ of 3.44 with that of the extract of araçá fruit witch in the same analysis obtained an $\mathrm{EC}_{50}$ of 6.37 at $\left(74^{\circ} \mathrm{C}\right.$ and $\left.6 \mathrm{~min}\right)$, it is noted that the extract of cambuci has higher antioxidant activity, twice more effective, than araçá [17].

The effect of the process variables, Temperature $(\mathrm{T})$ and Static time (St), on antioxidant activity were evaluated statistically. The Pareto diagram Fig. (2), shows that both variables significantly influence antioxidant activity and that the effect of the interaction between the variables $(\mathrm{T} \times \mathrm{St}) \mathrm{did}$ not present a significant influence.

The ANOVA for first and second order models, presented in Table 4, showed that, for the first order model, at least one of the variables had a significant effect on antioxidant activity; the model was significant since $F_{\text {calc }}>F_{\text {tab }}$. However, for the second order model, none of the variables had a significant effect on antioxidant activity since $\mathrm{F}_{\text {calc }}<\mathrm{F}_{\text {tab }}$, indicating a quadratic non-predictive model (Table 4). The first order mathematical model (Eq. 4), with the significant terms marked with an asterisk $(*)$, was used to generate the response surface, indicating the influence of the variables in this response.

$$
E C_{50}=7.39^{*}+3.38 T^{*}+3.59 S t^{*}-1.74 T \times S t
$$

It was possible to infer that the independent variables $\mathrm{T}$ and St influenced positively the $\mathrm{EC}_{50}$ and, consecutively negatively the antioxidant activity.

The response surface generated by the first order model Fig. (3), for the temperature and static time interval studied in

Table 4. Analysis of variance (ANOVA) for antioxidant activity of the Cambuci extracts from the experimental design (residual error).

\begin{tabular}{|c|c|c|c|c|c|}
\hline $\begin{array}{l}\text { Source of } \\
\text { Variation }\end{array}$ & $\begin{array}{c}\text { Sum of } \\
\text { Squares }\end{array}$ & $\begin{array}{c}\text { Degrees of } \\
\text { Freedom }\end{array}$ & $\begin{array}{l}\text { Medium } \\
\text { Square }\end{array}$ & Fcalc & Ftable \\
\hline \multicolumn{6}{|c|}{ First order model } \\
\hline Regression & 27.42 & 3 & 9.14 & \multirow{3}{*}{10.88} & \multirow{3}{*}{9.28} \\
\hline Residue & 2.53 & 3 & 0.84 & & \\
\hline Total & 29.95 & 6 & - & & \\
\hline \multicolumn{6}{|c|}{ Second order model } \\
\hline Regression & 21.10 & 5 & 4.22 & \multirow{3}{*}{0.79} & \multirow{3}{*}{5.05} \\
\hline Residue & 26.75 & 5 & 5.35 & & \\
\hline Total & 47.85 & 10 & - & & \\
\hline
\end{tabular}



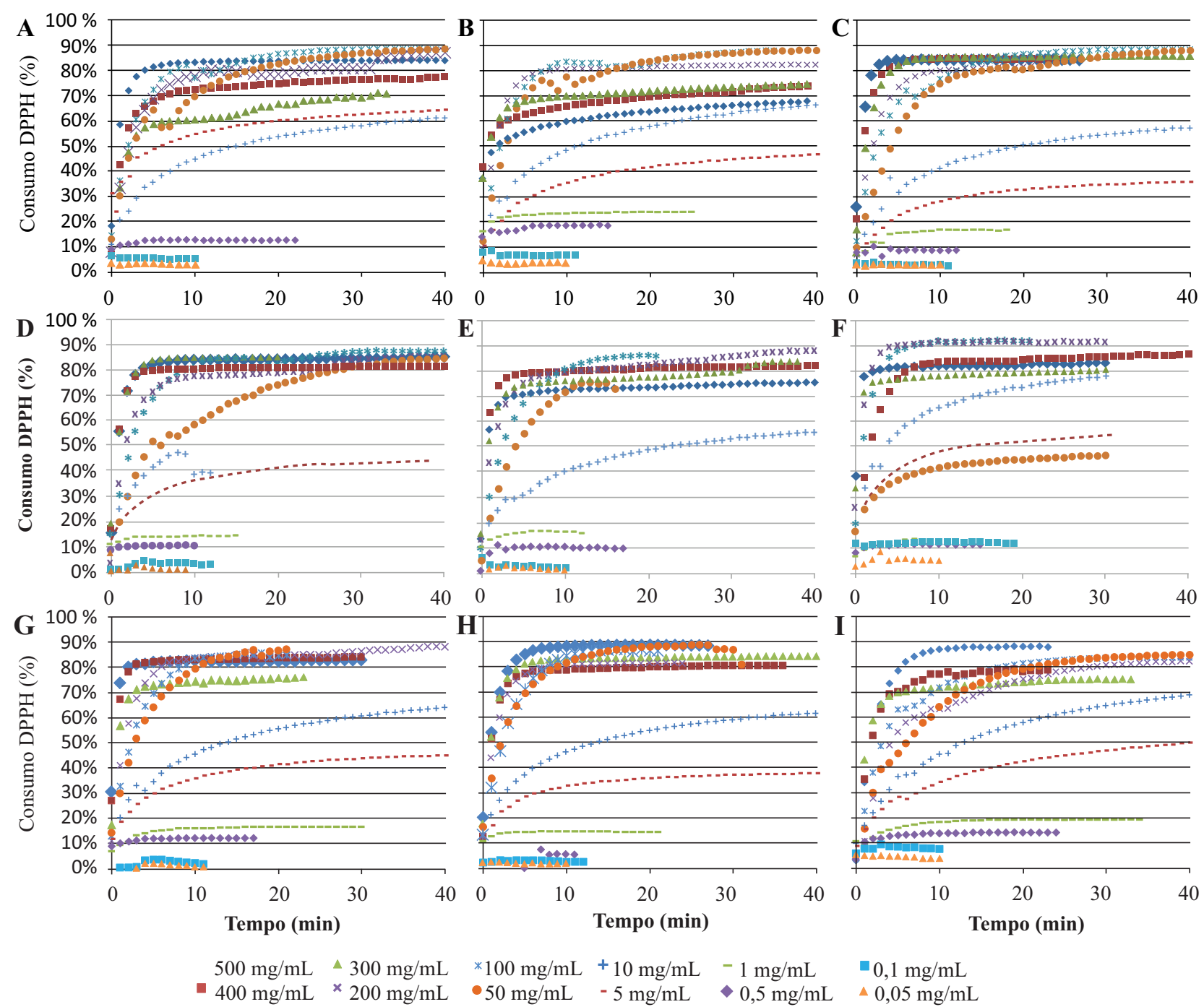

Fig. (4). Kinetics of DPPH radical reduction due to the antioxidant action of the ethanolic extracts of Cambuci obtained by different CCD assays. A) assay 1 ; B) assay 2 ; C) assay 3 ; D) assay 4 ; E) assay 5 ; F) assay 6 ; G) assay 7 ; H) assay 8 ; I) central point.

the DCCR, shows that both variables positively influence the $\mathrm{EC}_{50}$ value, indicating that the higher the temperature and the higher the static contact time between the solvent and matrix, the smaller the antioxidant activity of the extracts.

According to the data obtained, it was possible to notice a certain divergence among the optimized region for each response analyzed in function of the independent variables static time and the temperature. It has been found that it is not possible to determine an extraction condition which could generate a high yield and high TPC together with high antioxidant activity.

Thinking about industrial production, therefore, they must analyze what is its focus on production. It is more important to obtain extracts with high antioxidant activity, it is known that they will neither have a high yield nor high TPC. If the focus is higher yield, there will not be a great antioxidant activity but will have an intermediate value of phenolic compounds.

\section{CONCLUSION}

The ethanolic extract of cambuci presented a high yield under the employed extraction conditions, with a tendency to increase with an increase of the temperature and the time of contact between the solvent and the vegetal matrix. With the use of the proposed experimental design, it was possible to optimize the extraction of total phenolic compounds from the sample. Cambuci ethanolic extracts also had a high antioxidant activity, which was expected due to the high phenolic compound content. Therefore, the experimental process resulted in cambuci extracts that were rich in phenolic compounds and excellent natural antioxidants. These compounds are greatly beneficial for health, and being present in such high quantities gives cambuci extracts great potential to be applied in the food and pharmaceutical industries. This research shows a relatively fast extraction method that uses a little solvent to obtain the natural compounds of an Atlantic Forest fruit that is threatened with extinction. It is expected that the presented data show the potential for exploitation of these fruits. 


\section{LIST OF ABBREVIATIONS}

$\begin{array}{lll}\text { CCD } & = & \text { Central Composite Design } \\ \text { DPPH } & = & \text { 2,2-diphenyl-1-picrylhydrazyl } \\ \text { EC }_{50} & = & \text { Efficient Concentration } \\ \text { GRAS } & = & \text { Generally Recognized As Safe } \\ \text { PLE } & = & \text { Pressurised Liquid Extraction } \\ \text { RSA } & = & \text { Response Surface Analysis } \\ \text { St } & = & \text { Static Time } \\ \text { T } & = & \text { Temperature } \\ \text { TPC } & =\text { Total Phenolic Content }\end{array}$

\section{ETHICS APPROVAL AND CONSENT TO PARTI- CIPATE}

Not applicable.

\section{HUMAN AND ANIMAL RIGHTS}

No animals/humans were used for studies that are basis of this research.

\section{CONSENT FOR PUBLICATION}

Not applicable.

\section{AVAILABILITY OF DATA AND MATERIALS}

Not applicable.

\section{FUNDING}

We would like to acknowledge the Fundação de Amparo à Pesquisa do Estado de São Paulo (FAPESP) for research financial support, Processo no 2016/13460-8, the University of São Paulo (USP) for the undergraduate scholarship, the Coordenação de Aperfeiçoamento de Pessoal de Nível Superior, Brasil (CAPES) for the PhD scholarship, Finance Code 001 . We would also like to acknowledge the Conselho Nacional de Desenvolvimento Científico e Tecnológico (CNPq), Processo no 306317/2016-8.

\section{CONFLICT OF INTEREST}

The authors declare no conflict of interest, financial or otherwise.

\section{ACKNOWLEDGEMENTS}

Declared none.

\section{REFERENCES}

[1] BRASILEIRO CF. Lei $\mathrm{n}^{\circ}$ 12651, de 25 de maio de 2012. Brasília: Diário Oficial da União 2012

[2] SANCHES MCR. Caracterização do Fruto Cambuci (Campomanesia phaea) e efeito da destanização sobre o potencial funcional in vitro. Faculdade de Ciencias Farmaceuticas 2013.

[3] SILVA IG. Estudo de caracterização do fruto cambuci [Campomanesia phaea (O. Berg.) Landrum] e sua aplicação no processamento de geléia. Bol Cent Pesqui Process Aliment 2012; 30(1)

[4] Bianchini FG, Balbi RV, Pio R, Silva DF, Pasqual M, Vilas Boas EV. Caracterização morfológica e química de frutos de cambucizeiro. Bragantia, Campinas 2016; 1;75(1): 10-8.

[5] CATANEO CB. Atividade antioxidante e conteúdo fenólico do resíduo agroindustrial da produção de vinho Ciências de alimentos . 2008; 29: pp. 93-102.

[6] Baiano A, Del Nobile MA. Antioxidant compounds from vegetable matrices: Biosynthesis, occurrence, and extraction systems. Crit Rev Food Sci Nutr 2016; 56(12): 2053-68.

[http://dx.doi.org/10.1080/10408398.2013.812059] [PMID: 25751787]

[7] Prado A. Composição fenólica e atividade antioxidante de frutas tropicais Dissertação (Mestrado). Piracicaba: Escola Superior de Agricultura, Universidade de São Paulo 2009.

[8] Jorge N. ANGELO PM Compostos fenólicos em alimentos - uma breve revisão. Portal de Revistas - SES 2007; Vol. 66.

[9] PEREIRA CV. Extratos Bioativos De Frutos Amazônicos por Quimica Verde: Extração Por Líquido Pressurizado (PLE) e fluído supercrítico (SFE) Programa multi-institucional de pós graduação em Biotecnologia 2015.

[10] CIDADE-BRASIL . Município de Pirassununga https://www. cidade brasil . com. br /municipio-pirassununga.html2017.

[11] AOAC . Official Methods of Analysis of AOAC International. 18th ed. Gaithersburg: AOAC International 2005.

[12] SINGLETON VL. ROSSI JA. Colorimetry of total phenolics with phosphomolybdic-phosphotungstic acid reagents. Am J Enol Vitic 1965; 16(3): 144-58.

[13] Brand-Williams W. CUVELIER ME, BERSET CLWT. Use of a free radical method free radical method to evaluate antioxidant activity. Lebensm Wiss Technol 1995; 28(1): 25-30.

[http://dx.doi.org/10.1016/S0023-6438(95)80008-5]

[14] Duarte-Almeida JM, Santos RD, Genovese MI, Lajolo FM. Avaliação da atividade antioxidante utilizando sistema $\beta$-caroteno/ácido linoléico e método de seqüestro de radicais DPPH. Ciência e Tecnologia de Alimentos 2006; 26(2): 446-52.

[http://dx.doi.org/10.1590/S0101-20612006000200031]

[15] DE OLIVEIRA NA. CORNELIO-SANTIAGO HP, FUKUMASU H DE OLIVEIRA AL. Green coffee extracts rich in diterpenes - Process optimization of pressurized liquid extraction using ethanol as solvent. J Food Eng 2017; 224: 148-55

[16] OliVEIRA AL. DESTANDAU E, FOUGERE L, LAFOSSE M. Isolation by Pressurized Fluid Extraction (PFE) and identification using CPC and HPLC/ESI/MS of phenolic compounds from Brazilian cherry seeds (Eugenia uniflora L.). Food Chem 2014; 145: 522-9. [http://dx.doi.org/10.1016/j.foodchem.2013.08.065] [PMID: 24128 509]

[17] BITTENCOURT GM. Avaliação da atividade antioxidante e antimicrobiana de extratos de araçá (Psidium Grandifolium Mart. Ex DC.) obtidos por líquido pressurizado (PLE) e por fluido supercrítico (SFE). 2018111 f Dissertação (Mestrado) - Faculdade de Zootecnia e Engenharia de Alimentos, Universidade de São Paulo, Pirassununga, 2018.

[18] Roesler R, Malta LG, Carrasco LC, Holanda RB, Sousa CA, Pastore GM. Atividade antioxidante de frutas do cerrado. Ciência e Tecnologia de Alimentos 2007; 27(1): 53-60. [http://dx.doi.org/10.1590/S0101-20612007000100010]

\section{(C) 2019 Firmiano et al.}

This is an open access article distributed under the terms of the Creative Commons Attribution 4.0 International Public License (CC-BY 4.0), a copy of which is available at: (https://creativecommons.org/licenses/by/4.0/legalcode). This license permits unrestricted use, distribution, and reproduction in any medium, provided the original author and source are credited. 